\title{
Thyroid hormone resistance detected by routine neonatal screening
}

\author{
Resistência ao hormônio tireoidiano detectada \\ por meio da triagem neonatal
}

Léa Maria Zanini Maciel',Patrícia Künzle Ribeiro Magalhães'

\begin{abstract}
SUMMARY
We report the clinical and laboratory findings, and molecular analysis of a Brazilian patient with resistance to thyroid hormone syndrome (RTH) detected by neonatal screening. The index case was born at term by normal delivery with $2,920 \mathrm{~g}$ and $45 \mathrm{~cm}$. TSH of the neonatal screening test performed on the $5^{\text {th }}$ day of life was of $13.1 \mu \mathrm{U} / \mathrm{mL}$ (cut-off $=10 \mu \mathrm{U} / \mathrm{mL}$ ). In a confirmatory test, serum TSH level was $4.3 \mu \mathrm{U} / \mathrm{mL}$, total T4 was $19 \mu \mathrm{g} / \mathrm{dL}$ (confirmed in another sample, Total T4 = $>24.0 \mu \mathrm{g} / \mathrm{dL}$ ), free T4 was $3.7 \mathrm{\eta g} / \mathrm{dL}$, and free T3 was $6.7 \mathrm{pg} / \mathrm{mL}$. Direct sequencing of the beta thyroid hormone receptor gene revealed mutation c.1357C >A (P453T), confirming the diagnosis of RHT. Family study demonstrated the presence of RTH in his 1-year-and-3-month-old sister, in his 35-year-old father, and in his 68-year-old paternal grandfather. All of them had goiter and only his father had received an erroneous diagnosis of hyperthyroidism. The present case shows that clinical evaluation and a judicious interpretation of totalT4/free T4 concentrations in a newborn recalled due to slightly altered neonatalTSH can contribute to the diagnosis of RTH. Arq Bras Endocrinol Metab. 2010;54(8):723-7
\end{abstract}

\section{SUMÁRIO}

O objetivo deste estudo é relatar o caso de um paciente brasileiro com resistência ao hormônio tireoidiano (RTH) detectado por meio da triagem neonatal. 0 caso índice nasceu de parto normal a termo com peso de $2.920 \mathrm{~g}$ e estatura de $45 \mathrm{~cm}$. Realizou o teste de triagem neonatal no quinto dia de vida com TSH neonatal $=13,1 \mu \mathrm{U} / \mathrm{mL}$ (valor de corte $=10 \mu \mathrm{U} / \mathrm{mL}$ ). OTSH confirmatório no soro foi de $4,3 \mu \mathrm{U} / \mathrm{mL}$, T4Total de $19 \mu \mathrm{g} / \mathrm{dL}$ (confirmado em outra amostra, T4Total $=>24,0 \mu \mathrm{g} / \mathrm{dL}$ ), T4 Livre de 3,7 $\eta \mathrm{g} / \mathrm{dL}$ eT3 Livre de $6,7 \mathrm{pg} / \mathrm{mL}$. O sequenciamento direto do gene do receptor $\beta$ do hormônio tireoidiano revelou a mutação c.1357C >A (P453T), confirmando o diagnóstico de RHT. $O$ estudo de sua família confirmou RTH em sua irmã (1 ano e 3 meses), em seu pai (35 anos) e em seu avô paterno (68 anos). Todos apresentavam bócio e apenas seu pai havia recebido o diagnóstico errôneo de hipertireoidismo. Este caso ilustra que a avaliação clínica e a interpretação criteriosa das concentrações de T4 Total/Livre em um recém-nascido, reconvocado por TSH neonatal discretamente alterado, poderão servir para o diagnóstico da RTH. Arq Bras Endocrinol Metab. 2010;54(8):723-7
Division of Endocrinology Department of Clinical Medicine Faculdade de Medicina de Ribeirão Preto, Universidade de São Paulo (FMRP-USP), Ribeirão Preto, SP, Brazil
Correspondence to: Léa Maria Zanini Maciel Av. Bandeirantes, 3900 14049-900 - Ribeirão Preto, SP, Brazil

Imzmacie@fmrp.usp.br

Received on Jul/16/2010 Accepted on Nov/15/2010

\section{INTRODUCTION}

$\mathrm{T}$ he resistance to thyroid hormone syndrome (RTH) is an inherited disease that is usually suspected when elevated serum thyroid hormone (TH) levels are associated with non-suppressed thyrotropin (TSH). There are no pathognomonic clinical findings for RTH; frequently, thyroid function tests are requested based on short stature, hyperactivity, and goiter are noted in children and adolescents (1).
We report a patient with $\mathrm{RTH}$ suspected at birth by analysis of blood obtained during routine neonatal screening. A later study of his family permitted the identification of other affected members.

\section{CASE REPORT}

The propositus was born at term by normal delivery (birth weight: 2,950 g; birth length: $45 \mathrm{~cm}$; head cir- 
cumference at birth: $32 \mathrm{~cm} ; 5$ ' Apgar score $=9$ ) with no untoward postnatal events, except for jaundice which regressed spontaneously. He was discharged from the hospital within 48 hours. A neonatal screening test was performed at day 5 of life and TSH was measured in a heel prick dried blood spot. TSH result was $13.1 \mu \mathrm{IU} /$ $\mathrm{mL}$ of blood, above the cut-off level $(10 \mu \mathrm{IU} / \mathrm{mL})$, and the infant was called for evaluation.

Clinical evaluation at 15 days of life revealed that the infant's weight was $3,280 \mathrm{~g}$ and his height was 50.5 $\mathrm{cm}$. He was in good general conditions, with jaundice (zone II), heart rate (HR) of $140 \mathrm{bpm}$, anterior fontanelle of $3 \times 2 \mathrm{~cm}$ and posterior fontanelle of $1.5 \mathrm{~cm}$; goiter was absent on palpation.

Family history: the mother, a healthy 19-year-old woman, had an uneventful pregnancy and did not use medications. She reported a previous pregnancy 1 year and 3 months earlier, also uneventful. The father, a 35-year-old man, reported that he had started to have tremors, nervousness, fatigue, asthenia, palpitations during exercise, hyperdefecation and insomnia since age 20 . He denied goiter, exophthalmia or changes in weight. He consulted with a doctor who performed blood tests and thyroid scintigraphy with the detection of thyroid disorder and prescription of antithyroid medication. He used the medication for one month and discontinued treatment by choice. Examination revealed a diffusely enlarged thyroid ( 3 times the normal size). The father reported that his paternal grandmother had a large goiter and that she had died at age 58 , on the occasion of a thyroidectomy. He has 3 living siblings, but he has no information about their health conditions. The sister of the index case, evaluated at 1 year and 11 months of age, was born at term by normal delivery with a birth weight of $2,225 \mathrm{~g}$ and a birth length of $45 \mathrm{~cm}$. She was submitted to a neonatal screening test for which the result obtained was normal. She walked at the age of 1 year and 3 months. According to her parents, the child is very agitated and nervous. Examination revealed the presence of goiter (thyroid twice the normal size), HR of $124 \mathrm{bpm}$, and increased skin temperature and moisture. Weight $=9.4 \mathrm{~kg}(\mathrm{P} 3)$; height $=84 \mathrm{~cm}(\mathrm{P} 50)$.

Laboratory tests for the whole family are listed in table $\mathrm{l}$ and were compatible with RTH.

In view of these results, the paternal grandfather of the index case was called for an evaluation. A retired rural worker, at 68 years of age he was in good health and had not noticed his goiter, even though it was visible upon clinical examination. His HR was $72 \mathrm{bpm}$ and his thyroid was diffusely enlarged (3 times the normal size), with an irregular surface. His lab tests were also compatible with RTH $(\mathrm{TSH}=4.4 \mu \mathrm{IU} / \mathrm{mL}, \mathrm{FT} 4=2.6$ $\mathrm{ng} / \mathrm{dL} ; \mathrm{FT} 3=5.4 \mathrm{pg} / \mathrm{mL})($ Table $\mathrm{l})$.

Molecular study of the family was performed by genomic extraction of peripheral blood DNA using a previously described method (2). Exons 7, 8, 9, and 10 of the thyroid hormone receptor $\beta$ gene $(T R \beta)$ were amplified by polymerase chain reaction (PCR), using as primers oligonucleotide sequences based on the normal sequence of the TR $\beta$ gene (2).The study revealed a missense mutation in exon 10 , in which a cytosineadenine substitution in nucleotide 1357 (codon 453) caused a proline-threonine substitution (p.P453T), confirming the diagnosis of RTH (Figure 1).

Family pedigree is presented in figure 2 .

\section{Analytical methods}

Neonatal TSH determination was done by time-resolved fluoroimmunoassay (AutoDELFIA neoTSH assay from PerkinElmer Wallac, Turku, Finland) and serum TT4, FT4, FT3 and TSH were measured by chemiluminescent method (Immulite, DPC Cirrus Inc., Los Angeles, CA, USA).

The study protocol was approved by the ethics committee of the University Hospital of the School of Medicine of Ribeirão Preto - University of São Paulo. Consent was obtained from the proband's parents and from his relatives.

Table 1. Laboratory profile of the case study family with resistance to thyroid hormone

\begin{tabular}{|c|c|c|c|c|c|}
\hline & Age & $\begin{array}{c}\text { TSH } \\
(\mu \mathrm{l} / \mathrm{mL})\end{array}$ & Free T4 (ng/dL) & Total T4 ( $\mu \mathrm{g} / \mathrm{dL})$ & $\begin{array}{l}\text { Free T3 } \\
(\mathrm{pg} / \mathrm{mL})\end{array}$ \\
\hline Index case & 15 days & 4.3 & 3.7 & $19.0^{*}$ & 6.7 \\
\hline Sister & 23 months & 5.6 & 3.5 & 17.3 & 10.3 \\
\hline Father & 35 years & 3.0 & 3.1 & 18.3 & 6.0 \\
\hline Grandfather & 68 years & 5.3 & 2.4 & - & 4.4 \\
\hline
\end{tabular}

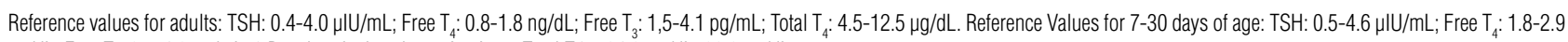
$\mathrm{ng} / \mathrm{dL} ;$ Free $\mathrm{T}_{3}: 2.7-4.6 \mathrm{pg} / \mathrm{mL} .{ }^{*}$ Results of other determinations: Total T4 $\geq 24.0 \mu \mathrm{g} / \mathrm{dL}, 22.2 \mu \mathrm{g} / \mathrm{dL}$. 

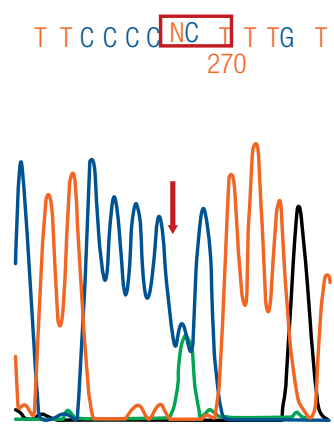

Figure 1. Electropherogram obtained by sequencing PCR fragments of the $\beta$ gene for thyroid hormone receptor, showing the $C .1357 C>A$ missense mutation (P453T) in heterozygosis in the index case. The same mutation was found in the other members of the family (index case's sister, father and grandfather). The arrows indicate the position of the mutation.

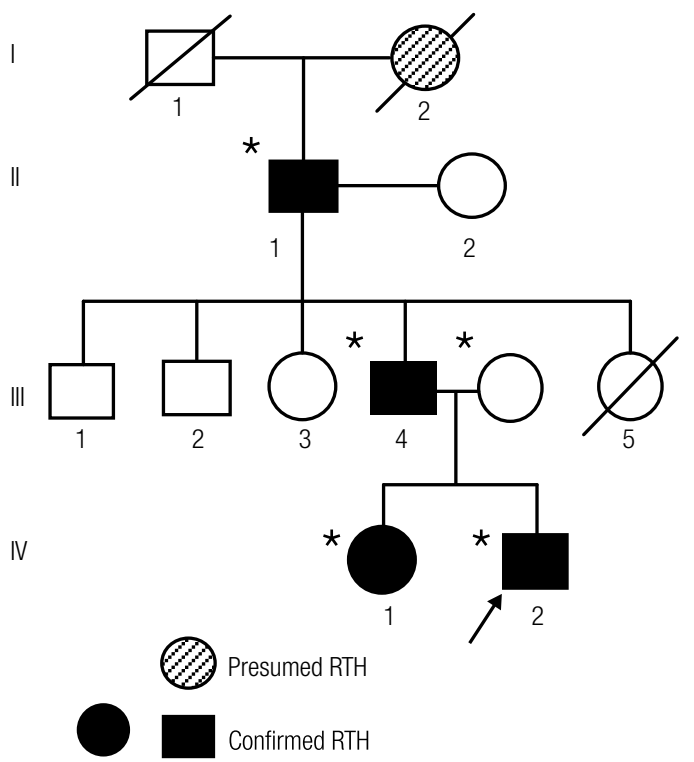

Figure 2. Pedigree of the case study family with thyroid hormone resistance (RTH). Circles: females; squares: males. Shaded symbols indicate the confirmation of the mutation. The arrow indicates the index case. Roman numerals identify the generation and Arabic numerals identify the individual. A line through the symbols indicates that the subject is deceased. An asterisk "*" indicates that blood was obtained from subject for analysis. Individual 12 died during surgery for goiter removal, possibly the $4^{\text {th }}$ generation ancestors of the propositus also had RTH.

\section{DISCUSSION}

We report a Brazilian patient with RTH due to mutation c.1357C $>$ A detected by neonatal screening.

In Brazil, the newborn screening program starts with the measurement of TSH in a blood spot dried on filter-paper and the cut-off level at our center is 10 $\mu \mathrm{U} / \mathrm{mL}$. The propositus presented a neonatal TSH $=$ $13.1 \mu \mathrm{U} / \mathrm{mL}$ and he was recalled for evaluation. Confirmatory serum TSH had normalized, but serial thyroid function tests continued to show elevated serum total and free T3 and T4 levels, above the normal limits for his age. Among persistent hyperthyroxinemia disorders, neonatal Graves' disease is the most prevalent and its occurrence is estimated at 1 in 10,000 to 50,000 newborn infants $(3,4)$. Usually the mothers are already known to have Graves' disease, even though thyrotoxicosis has been linked to reduced fertility in women (5). Antithyroid drugs cross the placenta to the fetus and, depending on the dose, newborn infants can have transient hypothyroidism until they metabolize and excrete the drug.

Congenital hyperthyroidism resulting from activating mutations of the TSH receptor has been reported $(6,7)$. Although these infants have clinical features of hyperthyroidism and goiter, this diagnosis was not reported at newborn screening, but the probably elevated neonatal $\mathrm{T} 4$ concentrations might have been detected by screening. Twenty to forty-two percent of children with McCune-Albright, a syndrome resulting from somatic cell mutations of the G-protein $\alpha$-subunit within the thyroid $(8,9)$, have also been reported to develop hyperthyroxinemia during the neonatal period, and hyperthyroidism present at birth has been reported in at least 2 cases (10-12). Other causes of hyperthyroxinemia are thyroxine-binding globulin (TBG) excess, familial dysalbuminemic hyperthyroxinemia (FDH), and RTH. Familial TBG excess, an Xlinked disorder, is estimated to occur in approximately 1 in 25,000 individuals (13). Patients with FDH usually show normal free T4 levels, but free T4 levels can be artificially increased when they are measured by standard immunoassay methods (14). The patients present no signs or symptoms of hyperthyroidism in these two situations.

RTH has been detected prenatally in an infant whose mother was known to carry the disease (15). A few babies have been studied during the neonatal period (16) and the biochemical picture seen at birth appears to be similar to that found in adulthood. Thus, RTH newborns can present with either borderline-elevated (16) or high TSH concentrations (17) associated with increased total and free T4 and T3 levels. Current screening programs for congenital hypothyroidism are not appropriate for an early detection of RTH since as they usually measure TSH in dried blood spots. 
Reports regarding the differential diagnosis of neonatal hyperthyroxinemia detected by neonatal screening are rare (18). Lafranchi and cols. (18) reported the first systematic study regarding neonatal screening for hyperthyroxinemia. They conducted a follow-up study of 80,884 infants screened in Oregon over a 20-month period. Enrolling 101 children with a T4 result $>3.0$ $\mathrm{SD}$, they detected 17 with persistent hyperthyroxinemia. Ten out of seventeen were considered to have TBG excess (elevated serum total T4 and T3 values with normal free T4, free T3, and TSH levels) and 5 of them who were tested showed increased serum TBG concentrations. Some of the 5 infants without TBG measurements were considered to have increased serum T4 binding other than TBG excess, therefore probably the FDH disorder. Two infants with elevated serum total and free T4 and T3 without suppressed TSH were considered to have $\mathrm{RTH}$ and a T3 $\beta$ receptor gene mutation was identified in one of them. No case of neonatal Graves' disease was detected in that study. The authors attributed the absence of neonatal Graves' disease patients to the diagnosis and antithyroid drug treatment of pregnant women with Graves' disease. The failure of Lafranchi and cols. (18) to detect cases of hyperthyroidism as a result of McCune-Albright syndrome or activating TSH receptor mutation is in agreement with the current estimates of the rare occurrence of these disorders.

Recently, Tajima and cols. (19) analyzed 83,232 newborns screened in Sapporo city, Japan, and detected 11 infants with persistent hyperthyroxemia. Eight patients were diagnosed as having Graves' disease, 7 out of 8 pregnant women were treated with antithyroid drug and only one unrecognized Graves' disease during pregnancy was detected by the screening. One patient with slightly elevated free T4 and normal TSH was diagnosed as having familial FDG. The other two patients with elevated free T4 without suppressed TSH were considered to have RTH and analysis of the thyroid hormone receptor $\beta$ gene confirmed the diagnosis.

In the present case report, we were able to detect an infant with RTH syndrome because his neonatal TSH obtained from a dried blood spot was above our cutoff level. The confirmatory serum TSH was normal for his age but his persistently elevated levels of total and free T3 and T4 required further investigation. A careful analysis of his family led us to suspect the diagnosis of RTH. His sister presents clinical characteristics attributable to RTH: she is thin, hyperkinetic and has goiter.
His father also has goiter and a history of treatment for thyrotoxicosis. As mentioned in previous studies (2), an erroneous diagnosis of thyrotoxicosis is not infrequent in RTH patients. The high thyroid iodine uptake associated with clinical signs and symptoms compatible with thyrotoxicosis, frequently leads to erroneous treatment with antithyroid drugs and/or radioactive iodine. His paternal grandfather had not noticed goiter. A very simple retired rural worker, he mentioned that his mother had died during surgery for goiter removal. Thus, possibly $4^{\text {th }}$ generation ancestors of the propositus also had RTH.

In conclusion, this case report shows that clinical evaluation and judicious interpretation of total $\mathrm{T} 4$ and free $\mathrm{T} 4$ concentrations in a newborn recalled due to slightly altered neonatal TSH can contribute to the diagnosis of RTH.

Disclosure: no potential conflict of interest relevant to this article was reported.

\section{REFERENCES}

1. Weiss RE, Refetoff S. Resistance to thyroid hormone. Rev Endocr Metab Disord. 2000;1(1-2):97-108.

2. Magalhães $P K$, Rodrigues Dare GL, Rodrigues dos Santos $S$, Nogueira CR, de Castro M, Zanini Maciel LM. Clinical features and genetic analysis of four Brazilian kindreds with resistance to thyroid hormone. Clin Endocrinol (Oxf). 2007;67(5):748-53.

3. Zimmerman D. Fetal and neonatal hyperthyroidism. Thyroid. 1999;9(7):727-33.

4. Weetman AP. Graves disease. N Engl J Med. 2000;343(17):1236-48.

5. Krassas GE, Poppe K, Glinoer D. Thyroid function and human reproductive Health. Endocr Rev. 2010;31(5):702-55.

6. Kopp P, van Sande J, Parma J, Duprez L, Gerber H, Joss E, et al. Brief report: congenital hyperthyroidism caused by a mutation in the thyrotropin-receptor gene. N Engl J Med. 1995;332(3):150-4.

7. de Roux N, Polak M, Couet J, Leger J, Czernichow P, Milgrom E, et al. A neomutation of the thyroid-stimulating hormone receptor in a severe neonatal hyperthyroidism. J Clin Endocrinol Metab. 1996;81(6):2023-6.

8. Feuillan PP, Shawker T, Rose SR, Jones J, Jeevanram RK, Nisula BC. Thyroid abnormalities in the McCune-Albright syndrome: ultrasonography and hormonal studies. J Clin Endocrinol Metab. 1990;71(6):1596-601.

9. Lee PA, Van Dop C, Migeon CJ. McCune-Albright syndrome. Long-term follow-up. JAMA. 1986;256(21):2980-4.

10. Yoshimoto $M$, Nakayama $M$, Baba T, Uehara $Y$, Niikawa $N$, Ito $M$, et al. A case of neonatal McCune-Albright syndrome with Cushing syndrome and hyperthyroidism. Acta Paediatr Scand. 1991;80(10):984-7.

11. Mastorakos G, Mitsiades NS, Doufas AG, Koutras DA. Hyperthyroidism in McCune-Albright syndrome with a review of thyroid abnormalities sixty years after the first report. Thyroid. $1997 ; 7(3): 433-9$.

12. Schwab KO, Gerlich M, Broecker M, Söhlemann P, Derwahl M, Lohse MJ. Constitutively active germline mutation of the thyro- 
tropin receptor gene as a cause of congenital hyperthyroidism. $\mathrm{J}$ Pediatr. 1997;131(6):899-904.

13. Refetoff $\mathrm{S}$. Inherited thyroxine-binding globulin abnormalities in man. Endocr Rev. 1989;10(3):275-93.

14. Pohlenz J, Sadow PM, Koffler T, Schönberger W, Weiss RE, Refetoff S. Congenital hypothyroidism in a child with unsuspected familial dysalbuminemic hyperthyroxinemia caused by a mutation $(\mathrm{R} 218 \mathrm{H})$ in the human albumin gene. J Pediatr. 2001;139(6):887-91.

15. Asteria C, Rajanayagam O, CollingwoodTN, Persani L, Romoli R, Mannavola D, et al. Prenatal diagnosis of thyroid hormone resistance. J Clin Endocrinol Metab. 1999;84(2):405-10.
16. Weiss RE, Balzano S, Scherberg NH, Refetoff S. Neonatal detection of generalized resistance to thyroid hormone. JAMA. 1990;264(17):2245-50. Erratum in: JAMA. 1991;265(7):869.

17. Wong GW, Shek CC, Lam ST, Tsui MK, Leung SS. Detection of resistance to thyroid hormone by cord blood screening. Acta Paediatr. 1995;84(3):335-6.

18. Lafranchi SH, Snyder DB, Sesser DE, Skeels MR, Singh N, Brent $\mathrm{GA}$, et al. Follow-up of newborns with elevated screening T4 concentrations. J Pediatr. 2003;143(3):296-301.

19. Tajima T, Jo W, Fujikura K, Fukushi M, Fujieda K. Elevated free thyroxine levels detected by neonatal screening system. Pediatr Res. 2009;66(3):312-6. 